\title{
ABRAZÍV VÍZVÁGÁS NUMERIKUS MODELLEZÉSE
}

\author{
Hervai Dávid Dominik ${ }^{a}$, Safranyik Ferenc ${ }^{b^{*}}$ \\ ${ }^{a}$ ELTE Informatikai, Kar, Savaria Múszaki Intézet, Gépészmérnöki BSc, 3. évf. \\ ${ }^{b}$ ELTE Informatikai, Kar, Savaria Müszaki Intézet, egyetemi docens
}

\begin{abstract}
ABSZTRAKT
Vizsgálatunk során az ipar számos területén alkalmazott abrazív vízvágással foglalkoztunk. A vizsgálat az említett megmunkálási eljárás során fellépő hibajelenségek tanulmányozására irányult. A munkánk célja az volt, hogy a megmunkálás során fellépó elhajlás jelenségét numerikus módszer segítségével modellezzük, majd a modellt összehasonlítsuk egy valós vágaton végzett mérések eredményeivel. A megmunkálás során nagy sebességek és elmozdulások lépnek fel, ezért explicit dinamikai modellt készítettünk, amelyben az abrazív sugarat SPH-, míg a lemezt hagyományos Lagrangetestként írtunk le. A szimulációt értékelve a modellen megfigyelhetô a valóságban is fellépő vágási rés ferdesége, miszerint a belépố oldalon nagyobb átmérőjü a vágási rés, mint a kilépó oldalon.
\end{abstract}

Kulcsszavak: vízvágás, abrazív, SPH, oldalferdeség

\section{Bevezetés}

Az abrazív vízsugaras vágást elsóként az 1930-as években, a bányászatban alkalmazták, az általánosabb ipari szintú felhasználása az 1960-as években kezdődött [1]. Ez egy olyan korszerú technológia, ami a késóbbiekben sokkal nagyobb jelentôséget kap az ipar számos területén, mert ahogy az ilyen típusú gépek fejlôdnek, egyre szélesebb skálát fednek le a megmunkálható anyagok, valamint a megvalósítható termékek között. Mivel ez az eljárás korszerú, így rengeteg lehetôség rejlik benne, de ez magával hordozza azt is, hogy még viszonylag kevés az ehhez kapcsolódó szakirodalom, fóleg az olyanok, amelyek az elméleti síkon megfogalmazott felvetések és a gyakorlati példák között teremtenek valamilyen kapcsolatot. Az eljárás elvét tekintve viszonylag egyszerú, azonban alkalmazása során figyelnünk kell a technológiai paraméterek helyes megválasztására.

Az abrazív vízsugaras vágás anyagleválasztó eljárás, mert a vágási út mentén a sugár a munkadarabot „elkoptatja”. Megmunkáláskor egy igen kis átmérôjú és nagy nyomású víz vagy víz és kerámia szemcsék elegyéból álló sugár halad extrém nagy sebességgel (500-1500 m/s) a megmunkálandó felület felé majd, amikor a felülettel találkozik, akkor azt elkoptatja. A vágott felület igen jó minőségú, bizonyos esetekben utómegmunkálás sem szükséges, illetve igen összetett geometriájú termékek is gyárthatók nagy sorozatban. A technológia felületi megmunkálásra is alkalmas, ilyenkor nem vágják át teljesen a nyers munkadarabot, hanem csak a felületét munkálják meg, pl. tisztítási célból. Tehát két esetet különböztetünk meg [1, 2]:

- vágási eljárások: a teljes anyagvastagságot munkáljuk meg;

- felület megmunkáló eljárások: csak egy adott vastagságot munkálunk meg.

A technológiának két alapvetô változata van:

- tisztán vízsugaras megmunkálás WJ (WJ = water jet);

- abrazív vízsugaras megmunkálás, melyet tovább bonthatunk ASJ (szuzpenziós módszer, ahol a keverés a vágófejen kívül történik) vagy AWJ (a keveredés a vágófejben jön létre) eljárásokra.

(C) ELTE, Informatikai Kar, Savaria Múszaki Intézet, 2021

*Kapcsolattartó: Safranyik Ferenc, sf@inf.elte.hu

https://doi.org/10.37775/EIS.2021.1.2 


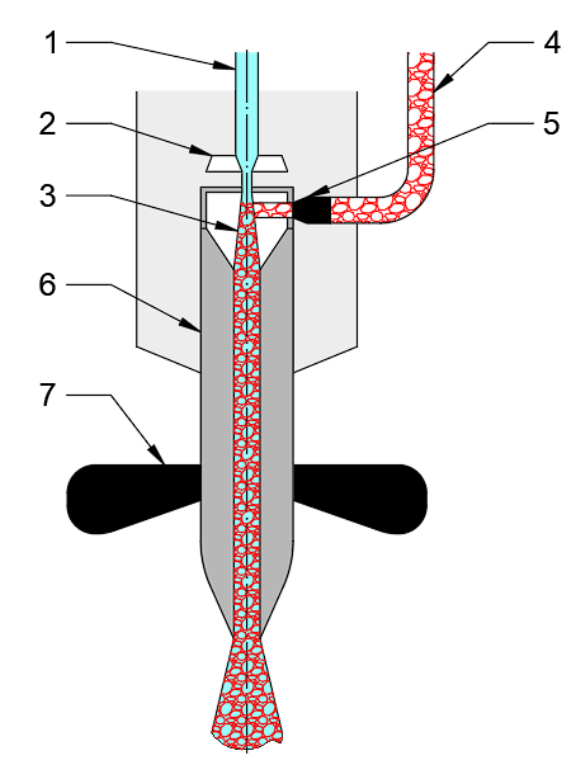

1. ábra: A vágófej metszete (AWJ kialakítás), részei: 1: nagynyomású víz, 2: fókuszáló, 3: keverókamra, 4: abrazív szemcsék, 5: injektor, 6: fúvóka, 7: védôsapka [1]

Az elsố esetben a sugár csak tisztán folyadékból áll (leggyakrabban vízból). A második esetben a vízsugárhoz adnak valamilyen abrazív (koptató) hatású szemcséket. A hozzáadott szilárd részecskék jelentősen növelik az eljárás termelékenységét. A megmunkálás során a megmunkáló gép típusától függő́en több fajta vágófej kialakítás létezhet. A vágófej feladata a sugár megfelelô pozicionálása, fókuszálása (1. ábra) szükség esetén a keveredés biztosítása a víz és az abrazív szemcsék között [1].

\subsection{Technológiai problémák}

A vágási rés alakja, hibái

Abrazív vízsugaras vágás során a sugár a nagy mozgási energiával érkezik a felületre, majd a vágás során, ahogy egyre beljebb hatol az anyagba, veszít az energiájából, ennek látható következménye is van. Az elméletileg tökéletes vágási képhez képest (ami tisztán egyenes oldalakat eredményez) jól látható, hogy a vágott felület közel sem egyenes, különböző egyenetlenségek vehetôk észre, illetve az is látszik, hogy ahol a sugár belép az anyagba, szélesebb a vágás, mint ahol kilép. A felület esetleges egyenetlensége mellett, ez az egyik fő probléma, az úgy nevezett oldalferdeség (2. ábra). Az oldalferdeséget az egyszerúsítés miatt, ténylegesen úgy vesszük számításba, mintha a vágott oldalak bizonyos mértékben eltérnének a függólegestôl [2].
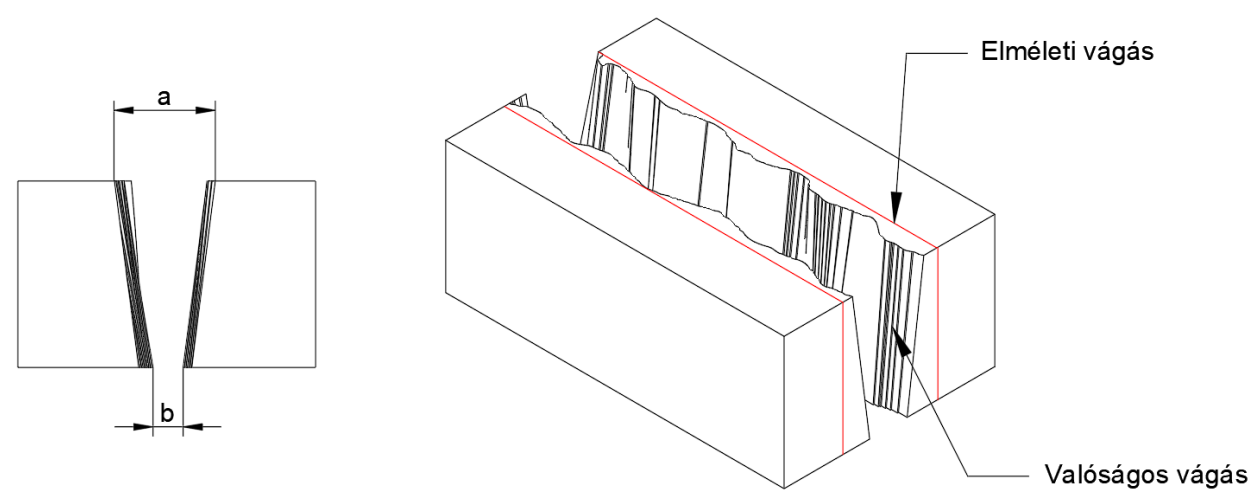

2. ábra: A vágási rés alakja [2] 


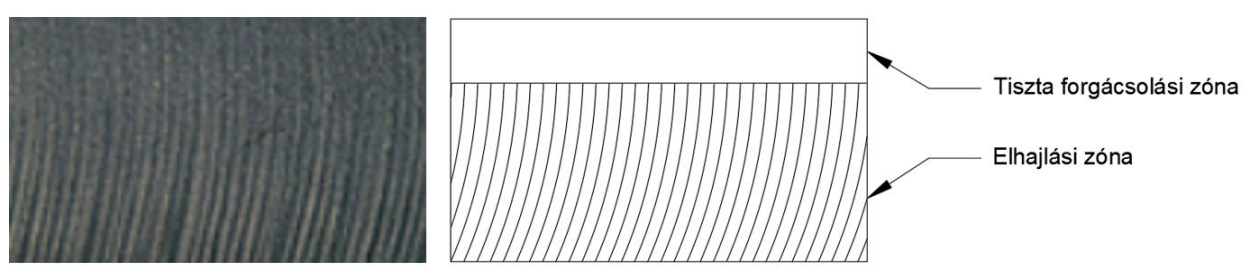

3. ábra: Az elhajlás jelensége [3]

\section{Az elhajlás jelensége}

Mint minden forgácsoló megmunkálás esetén, itt is szükség van a munkadarab és a „szerszám” közötti elmozdulására (előtolásra). A megmunkálás akkor lehet a leggyorsabb, ha az elótolás értékét növeljük, hiszen egységnyi idő alatt nagyobb utat tesz meg a vágófej. Azonban a megmunkálás során, ahogy a sugár halad, két vágási zónát hoz létre a felületen. A felsố részeken tiszta anyagleválasztás látható, azonban az alsóbb rétegekben, (az elôzô hibához hasonlóan) a sugár veszít az energiájából, ezért elhajlik, ami rosszabb vágási minőséget eredményez (3. ábra).

\subsection{A folyamat modellezése}

Az SPH (Smoothed Particle Hydrodynamics, vagy magyarul: Simított Részecskés Hidrodinamika), egy Lagrange-féle, teljesen háló független módszer [3]. A módszer kifejlesztése Joseph J. Monaghan nevéhez füződik, aki az asztrofizikában alkalmazta ezt a eljárást különbözố csillagközi gázok viselkedésének modellezésére [4]. Mivel a módszer különálló elemek definiálásából adódóan igen jól alkalmazható különbözô közegek áramlásának vizsgálatakor, ezért a vízvágás vizsgálatához is ideális, mert a folyadék és abrazív szemcse sugár tipikus áramlástani probléma. A módszer fontos tulajdonsága, hogy minden egyes elemet, adott tulajdonságokkal kell ellátnunk, pl. sưrúség, nyomás, tömeg, térbeli helyzet, sebesség stb. Ezeket a paramétereket minden időpillanatban ismerjük. Kezdetben mi határozzuk meg ezeket a paramétereket (pl. 0. idôpillanatban), azonban az SPH módszer lényege, hogy folytonos függvények és deriváltjaik értéke diszkrét pontok felhasználásával közelíthetô, ami annyit jelent, hogy egy adott elem aktuális tulajdonságait mindig a szomszédos részecskék pozíciójából és tulajdonságából számítjuk $[5,6]$. Az SPH módszer egy olyan numerikus eljárás, melynek alapja az integrál-interpoláció. Mint minden interpoláció során, itt is egy függvénnyel keressük a megoldást, ebben az esetben ezt magfüggvénynek nevezik. A magfüggvény segítségével egy adott részecske közelében lévố szomszédos elemek fizikai tulajdonságait közelítjük. Ez az interpoláció az alábbi alakban írható fel tetszóleges $A_{I}$ fizikai tulajdonságra vonatkozóan adott $\Omega$ tartományon [7]:

$$
A_{I}(\mathbf{r})=\int_{\Omega} A\left(\mathbf{r}^{\prime}\right) W\left(\mathbf{r}-\mathbf{r}^{\prime}, h\right) d \mathbf{r}^{\prime}
$$

ahol: $\quad$ - r, egy, az $\Omega$ tartományon belüli pont helyvektora,

- r' , a magfüggvényen belül lévố részecske helyvektora,

- $A_{I}(\mathbf{r})$, tetszóleges fizikai mennyiség a hely függvényében,

- $W$, a simító magfüggvény,

- $W\left(\mathbf{r}-\mathbf{r}^{\prime}\right)$, az $\varepsilon \longmapsto 0$ sugarú Dirac-delta függvény,

- $h$, a magfüggvény sugara, más néven a simító hosszúság.

Az egyenlet numerikus alakban:

$$
A_{s}(\mathbf{r})=\sum_{j} A_{j} \frac{m_{j}}{\rho_{j}} W\left(\mathbf{r}-\mathbf{r}^{\prime}, h\right),
$$


ahol: - $\quad j$, a simító hosszúságon belül lévố részecskék indexe,

- $m_{j}$, a $j$-edik részecske tömege,

- $\rho_{j}$, a $j$-edik részecske sưrúsége,

- $A_{h}$, a magfüggvény értéke a $j$-edik részecske helyén.

\subsection{Az SPH módszer alkalmazhatósága vízvágás modellezéséhez}

Ma és szerzôtársai [8] azt vizsgálták, hogyan lehet a különbözố numerikus eljárásokat alkalmazni az abrazív vágás modellezésére. Alkalmaztak Euler-féle megközelítést, klasszikus végeselemes modellt és SPH-VEM hibrid modellt. Az egyes módszerek különféle problémák megoldásához ideálisak.

Euler-Lagrange modell esetén lényegében a vágott anyagot hagyományos testként értelmezzük, és behálózzuk, valamint létrehozunk egy úgynevezett ellenôrzô térfogatot, amiben a folyékony közeg áramlik (esetünkben víz). Elônye a módszernek, hogy a nagy sebességeket ugyan tudja kezelni, de a nagy deformációkat ebben az esetben már csak nehezen. Amennyiben az áramló közeg kilépne az ellenőrzô térfogatból, annak határán úgy viselkedne, mintha határoló felületnek ütközne, ami torzítaná az eredményeket. Az ellenőrző térfogatot természetesen lehet bôvíteni, azonban ez a számítási kapacitás megnövekedését eredményezné, ezért ezt nem célszerû alkalmazni.

A második lehetőség a klasszikus VEM modell. Ennek előnye, hogy könnyú definiálni a geometriát és az anyagparamétereket, azonban a nagymértékú deformációt a háló torzulása miatt, már nem lehet kezelni (4/a ábra). A megmunkálás során a vízsugár jelentős deformációt szenved, így ennek a módszernek a használata sem célszerú.

A harmadik lehetôség az általunk is használt SPH-VEM hibrid modell, mely az elóbbiekben felsorolt módszerek elönyeit ötvözi, hiszen, ha a sugarat SPH modellnek vesszük, akkor az alkalmas a nagy deformációkra és sebességekre, míg a megmunkálandó lemez hagyományos VEM modellként felépítve is megfelelő (4/b ábra).

A szerzők munkája alapján tehát az abrazív vágáskor lejátszódó folyamatok modellezésére a hibrid SPH-VEM modell az egyik legjobb megoldás, mert nagy deformáció lép fel a sugárban, valamint a deformáció miatt a sugár elég nagy térfogatot betölt a vágás során (fröccsenô víz esete). A módszer másik előnye, hogy az anyagparaméterek és a geometria definiálása is viszonylag egyszerú.

\subsection{Célkitûzések}

A fentiek alapján célunk az, hogy az abrazív vízvágás során fellépô vágási rés hibát elfogadható hibahatáron belül modellezzük hibrid SPH-VEM módszerrel, annak érdekében, hogy késóbb ezt tovább fejleszthessük, hogy a sugár haladását is vizsgáljuk, valamint a kapott eredményeket felhasználva, akár késóbbi technológia optimálásra használjuk az eredményeket.

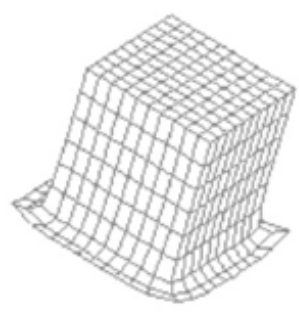

a)

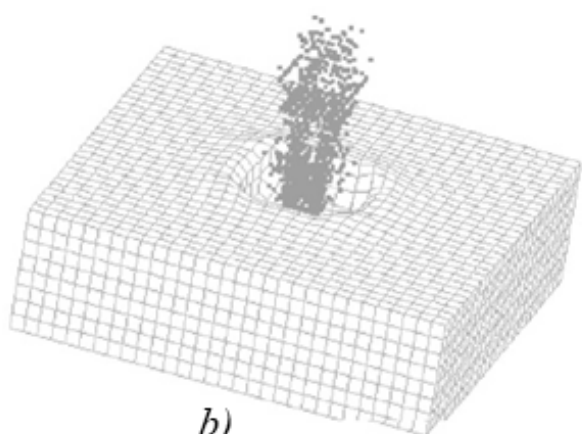

b)

4. ábra: a) A sugár nagy deformációja a VEM modellben, b) Sikeres szimuláció hibrid SPH-VEM modellen [8] 


\section{Lyukasztási folyamat SPH modellje}

A modell elkészítésének fô alapelve az volt, hogy a lehető legegyszerúbb, azonban az elvárt pontosságnak megfelelő modellt válasszuk. A folyamatban két test szerepel, egyik a munkadarab (lemez), a másik a sugár.

\subsection{A lemez anyagmodellje}

A munkadarab anyaga: AlMgSi0,5 ötvözet (EN AW 6060) [2]. Az anyagra jellemző többek közt: alumínium ötvözet, ezért könnyú, lágy, de a magnézium és szilícium segít a szilárdság növelésében, ezért jó mechanikai tulajdonságokkal rendelkezik, a környezet korrodáló hatásával szemben ellenálló [9]. Az anyagról több mechanikai tulajdonságot árul el a szakítódiagramja. Ezt a diagramot szakítóvizsgálattal veszik fel, amely során a fajlagos megnyúlást $(\varepsilon)$ mérik a keletkezô normál feszültség $(\sigma)$ függvényében [10].

A bilineáris anyagmodell két lineáris szakaszból áll, amelyek segítségével figyelembe vehetjük az anyag képlékeny viselkedését. Az elsô szakaszon, a folyáshatár eléréséig lineárisan rugalmasan viselkedik, karakterisztikáját a függvény meredeksége, azaz a rugalmassági modulus írja le. A második szakaszon, az úgynevezett tangens modulus mutatja meg a várható maradó alakváltozás mértékét [11]. A két diagramot egymásra helyezve kapjuk meg az alábbi ábrát (5. ábra).

A bilineáris anyagmodell paraméterei:

- $R_{e H}$, a folyáshatár,

- $\operatorname{tg}(\alpha)=E$, a rugalmassági modulus,

$-\operatorname{tg}(\beta)=E_{t}$, az érintő modulus,

- $\nu$, a Poisson-tényezó.

Az anyagmodell mellett szükség van tönkremeneteli paraméterekre is, mert ezeknek az értékeivel tudjuk szabályozni azt, mikor következik be a tönkremenetel (mikor szakad meg az anyagfolytonosság). Alapvetően tudjuk, hogy egy anyag adott pontjában a tönkremenetel akkor következik be, ha az adott pontjában a redukált feszültség eléri a folyáshatárt [12]. A szimuláció során, ha az általunk megadott határétéket eléri bármelyik elemben a keletkező legnagyobb főfeszültség, akkor azt töröljük. A másik ilyen jellemzô a megengedett legnagyobb alakváltozás. Alapvetően, a maximális alakváltozás a teljes tönkremenetel előtt számítható, ezen érték ismeretében, meghatározhatunk egy olyan határ-alakváltozást, amelynél nagyobb alakváltozás esetén töröljük az adott elemet a hálóból. Az anyagjellemzóket a 1. táblázatban ismertetjük.

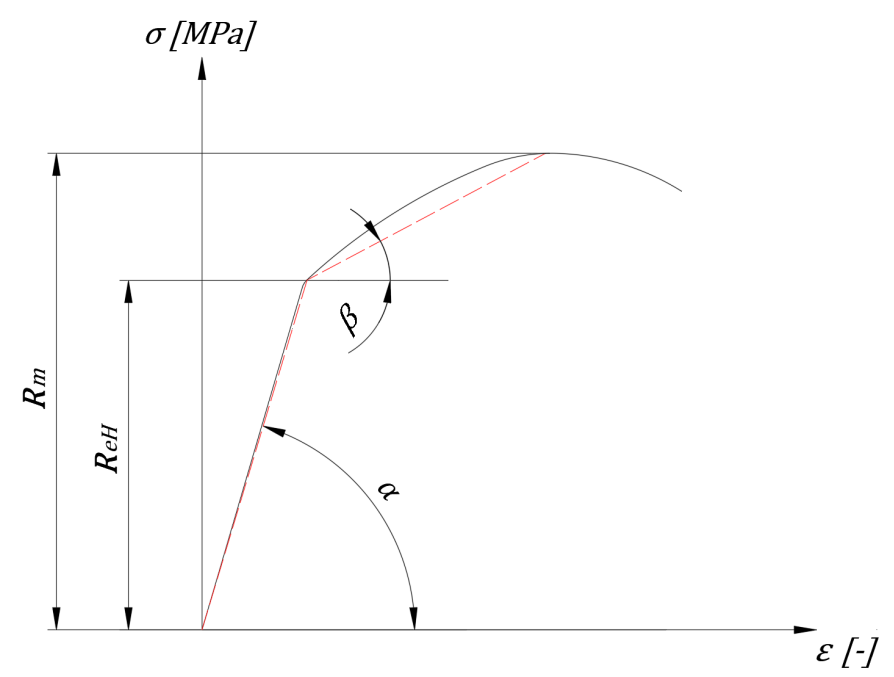

5. ábra: Alumínium szakítódiagramja (fekete) és a bilineáris anyagmodell (piros) [11] 
1. táblázat: A lemez anyagmodelljének paraméterei $[2,13]$

\begin{tabular}{l|c} 
Paraméter & Értéke \\
\hline Folyáshatár $\left(R_{e H}\right),[\mathrm{MPa}]$ & 206 \\
Rugalmassági modulus $(E),[\mathrm{GPa}]$ & 69 \\
Érintô modulus $\left(E_{t}\right),[\mathrm{GPa}]$ & 0,32 \\
Poisson-tényezô $(\nu),[-]$ & 0,3 \\
Sürüség $(\rho),\left[\mathrm{kg} / \mathrm{m}^{3}\right]$ & 2800 \\
Tönkremeneteli föfeszültség $\left(\sigma_{1, \max }\right),[\mathrm{MPa}]$ & 250 \\
Geometriai deformációs tényezó $(k),[-]$ & 0,2
\end{tabular}

2. táblázat: Az abrazív sugár sưrûségének számításához használt paraméterek [2]

\begin{tabular}{l|c|c} 
Paraméter & Víz & Abrazív szemcse \\
\hline Sûrúség $(\rho),\left[\mathrm{kg} / \mathrm{m}^{3}\right]$ & 997 & 3950 \\
Anyagáram $(W),[\mathrm{kg} / \mathrm{s}]$ & 0,033 & 0,00333
\end{tabular}

\subsection{Az abrazív sugár modellje}

A sugár felépítését tekintve SPH modell. A legfontosabb tulajdonsága a sugárnak, hogy két anyagból tevődik össze (abrazív anyag és víz). A szimuláció során az egyszerúsítés miatt ezt egy anyagként kezeljük. A számításhoz a legfontosabb sugár paraméterek: a sưrűség és az anyagáram (2. táblázat). A sugár előállításához szûrt vizet, és GARNET80 típusú gránátport használtak a szerzők [2]. A szükséges átlagsúrúséget a tömegáram-arányok alapján számítottuk ki. A teljes anyagáram:

$$
W=W_{v}+W_{s z}=0,033+0,00333=0,03633 \mathrm{~kg} / \mathrm{s} .
$$

A tömegáram-arányok alapján a sugár átlagos sürúsége számítható:

$$
\rho=\frac{W_{v}}{W} \rho_{v}+\frac{W_{s z}}{W} \rho_{s z}=1270 \mathrm{~kg} / \mathrm{m}^{3} .
$$

A sugár sưrúségét ennek megfelelően állítottuk be. Ez az egyik legfontosabb anyagjellemzô, hiszen mozgási energiája révén alakítja a fémet a sugár, ami elsôsorban a sûrúségtôl és a sebességtôl függ. Ahogyan a lemez anyagmodelljénél is szükség volt tönkremeneteli értékekere, úgy most is szükségünk van rá, ez esetünkben a nagy sebességú folyamatok modellezésénél használatos Rankine-Hugoniot állapotegyenlet [14]. Az állapotegyenlet értékeit az Ansys-Autodyn anyagkönyvtárából a víz tulajdonságaihoz rendelt értékekkel vettük figyelembe, itt két fontos érték szerepelt, a $C_{1}$ paraméter, melynek értéke $1647 \mathrm{~m} / \mathrm{s}$, illetve az $S_{1}$ paraméter, melynek értéke 1,921 volt.

\subsection{A geometriai modell}

Alapvetően két geometria szükséges, az egyik a lemez, amit vágni szeretnénk, ez a korábban bemutatott alumíniumból készült, vastagsága $4 \mathrm{~mm}$ volt. A sugár fontos tulajdonsága a sugárátmérô, amelyet alapvetően a fúvóka geometriája határoz meg. A geometriai ismertetéséból észrevehetjük, hogy szimmetrikus feladattal állunk szemben. Ezen okok miatt, a feladatot kétdimenziós, tengelyszimmetrikus problémaként modelleztük. Ezzel a módszerrel két téglalapra egyszerúsödik a geometria. A felsorolt egyszerúsítéseket alkalmazva, a lemezkorongot modellező felület 3x4 mm, míg a sugár 25 mm hosszú és 0,4 mm sugarú. A sugár távolsága a darabtól a kezdeti pillanatban 0,001 mm (6. ábra). A geometriai modellt Ansys Autodynben készítettem el (kék: sugár, szürke: lemez). 


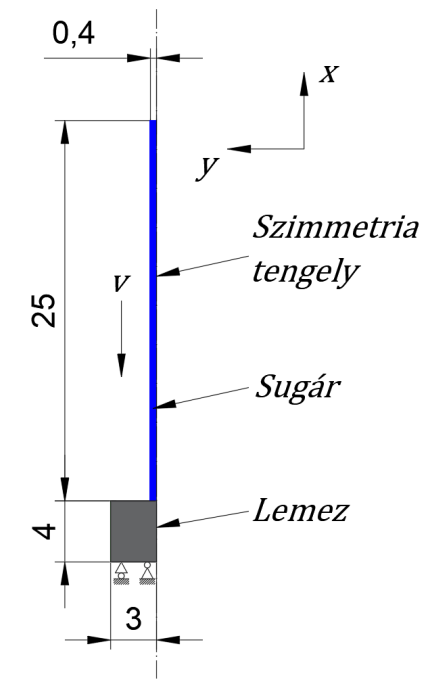

6. ábra: A geometriai modell

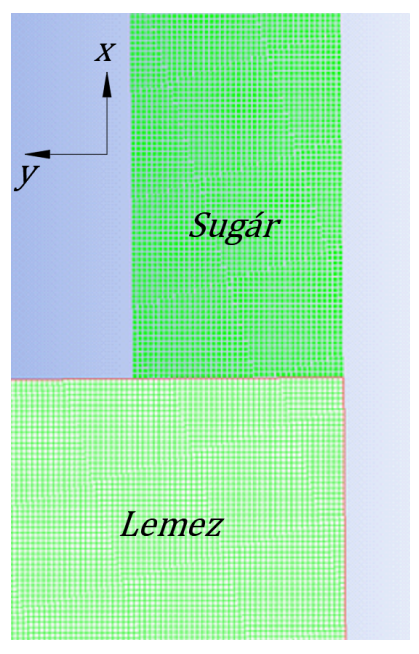

7. ábra: A részekre osztott geometria

\subsection{Diszkretizálás}

A végeselem szoftverek esetében kulcsfontosságú kérdés az úgynevezett hálózás. Ennek során határozzuk meg, hogy egy adott geometriát hogyan diszkretizáljon a szoftver. Esetünkben két különböző numerikus modell is van, a lemez és a sugár. A vízsugár a jellegéból adódóan SPH modell, ezért a két modell esetén más-más páramétereket kell megadnunk. Az általunk használt paramétereket a 2. táblázat tartalmazza. A numerikus megoldás előállításához szükséges a geometriát részekre osztani (diszkretizálni), valamint az így elkészült hálót a kritikus zónákban finomítani. Esetünkben a geometria tengelyszimmetrikus egyszerüsége miatt elég volt a lemez esetén lineáris közelítésû négyzet alakú, megegyezô elemeket, a sugár esetén pedig ugyanilyen méretú SPH részecskéket alkalmazni (7. ábra). A lemezt 47241 db, lineáris közelítésú, négyzet alakú, 0,015 mm élhosszúságú elemekre, míg a sugarat $23409 \mathrm{db}, 0,015 \mathrm{~mm}$ átmérôjü SPH részecskére osztottuk fel.

Korábban ismertettük az SPH módszert, ennek a megoldásnak fontos paramétere, a $h$ simítóhossz, amelyet eloozetes számítások alapján 0,001 mm-re vettük fel. A simítóhossz mellet a szimuláció jellegéból adódóan szükséges az idólépték definiálása. Az explicit idôintegrálásos megoldás során a szimulációs idóléptéket a számítási algoritmus, a rendszer energiaszintje alapján határozta meg, amely nem lehetett nagyobb $10^{-3}$ ms-nál. Jellemző értéke a szimuláció során $4,510^{-7} \mathrm{~ms}$ volt.

\subsection{Peremfeltételek}

Esetünkben két alapvető kényszert határozhatunk meg. Az elsô, hogy a lemez fix pozícióban maradjon, hiszen a megmunkálás során nem mozog. Ehhez a sebességet minden irányban 0-ra állítjuk, így a szimuláció során a darab nem mozdul el. A sugár fó paramétere a nyomása, ezt azonban nem tudjuk közvetlenül beállítani, de a nyomásból számolhatunk sebességet. A sebességet az alábbi összefüggéssel lehet számolni [2]:

$$
v=\mu \sqrt{\frac{2 p}{\rho}}
$$

ahol: - $\quad$, a veszteségi tényező (értéke 0,83 és 0,93 közötti),

- $p$, az alkalmazott nyomás,

- $\rho$, a sugár sürúsége.

Esetünkben a nyomás $300 \mathrm{MPa}$, a kilépô sugár sûrúsége $1270 \mathrm{~kg} / \mathrm{m}^{3}$, a veszteségi tényezô pedig 0,88. Ezek alapján a sugár kezdeti sebessége $604,86 \mathrm{~m} / \mathrm{s}$. 


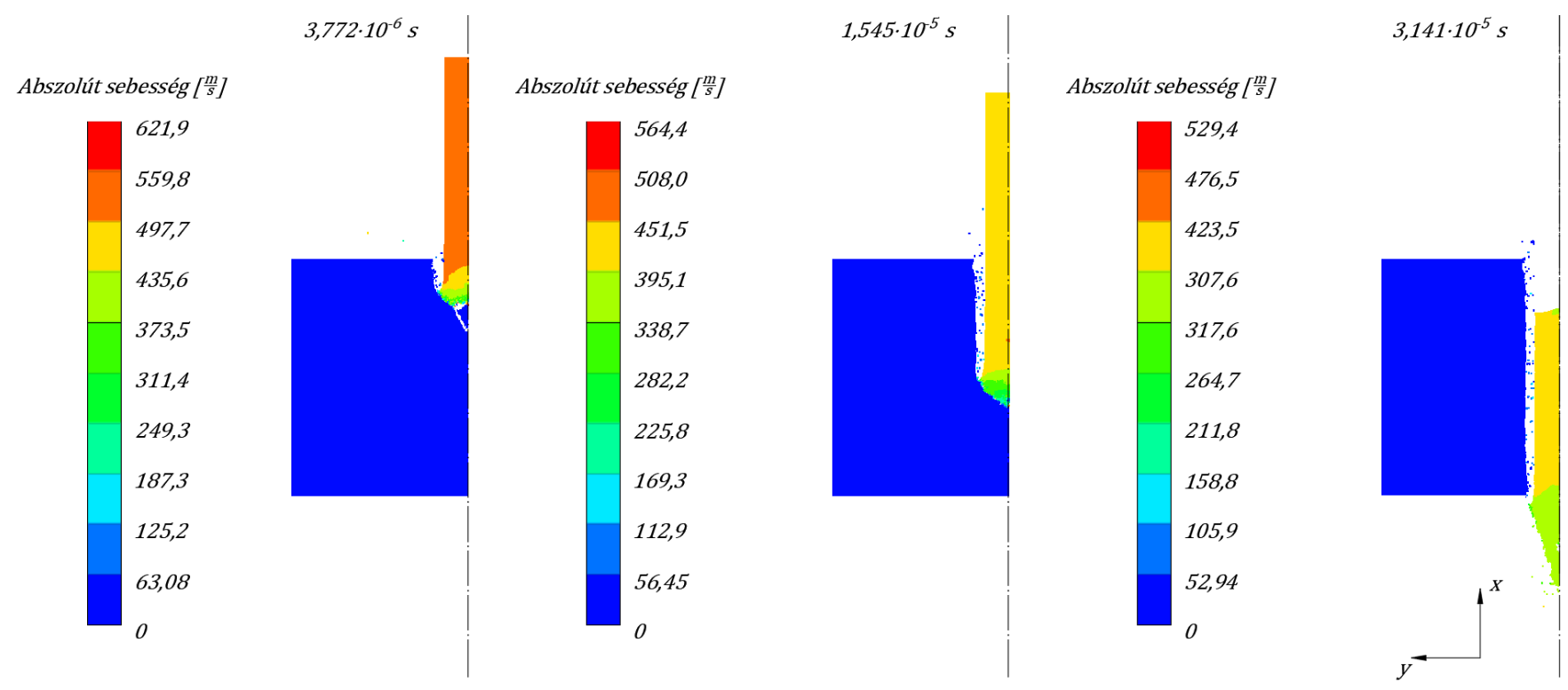

8. ábra: A sugár haladása az egyes idôpillanatokban

\section{Eredmények}

A szimulációt elvégezve értékelhető eredményt kaptunk, amin a geometriai méréseket el tudtuk végezni, így össze lehetett hasonlítani a valós lemezvágással [2]. A szimuláció során a sugár haladását figyelve látható, hogy ki- és belépéskor hogyan viselkedik az anyag. A szimuláció során lehetôségünk volt, hogy adott időközönként, a szoftver mentse el az adott állapotot, így nem csak a végeredményt láthatjuk, hanem köztes idôpillanatokban is vizsgálható a vágórés (8. ábrán). Az ábrán továbbá nyomon követhető, ahogy a sugár folyamatosan energiát veszt, és ezáltal csökken a sebessége.

A szimuláció fó célja a vágási rés alakjának modellezése majd hitelesítése. A valóságban ugyanilyen feltételek mellet kapott vágási rés alakját a (9. ábra) szemlélteti [2]. Ezt hasonlítottuk össze a szimulációs eredményekkel (10. ábra). A numerikus számítással kapott vágórés szélessége a belépó oldalon 7,1\%-kal, míg a kilépô oldalon 7,4\%-kal tér el a valós méretektől. A vágórés számított ferdesége pedig 14,7\%-kal nagyobb a mért értéknél.

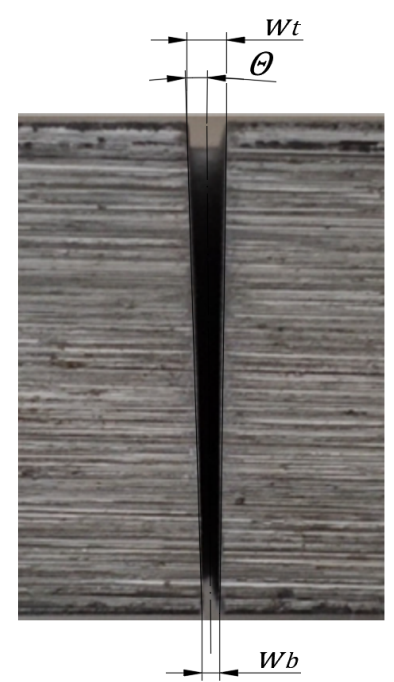

9. ábra: A vágási rés a valóságban [2]

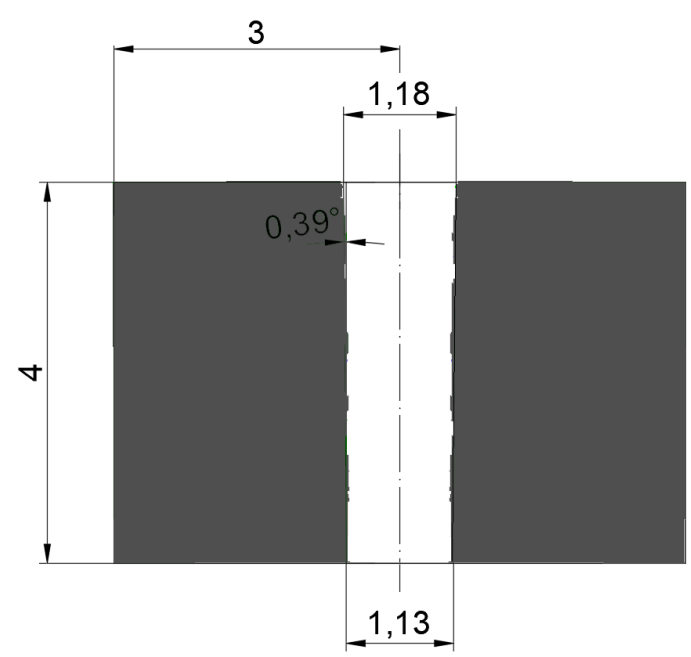

10. ábra: A szimuláció eredménye 


\section{Következtetések}

A kapott eredményeket értékelve úgy gondoljuk, hogy sikeresen le tudtuk modellezni az abrazív lyukasztási folyamatot. A szakirodalomban [2] leírt kísérletek eredményeit elfogadható hibával tudtuk reprodukálni, mert a 3 eredmény közül két esetben 10\%-nál kisebb hibával, míg az oldalferdeség esetén 15\%-nál kisebb hibával sikerült közelíteni a valós méréseket, tehát a modellezésünk sikeresnek tekinthetô. A számítás során láthatóvá vált, a haladás során, hogy amint egyre mélyebben hatol az anyagba a sugár, úgy csökken a keresztmetszete, ezzel okozva a ferdeséget (8. ábra). Mivel az abrazív sugárral történő lyukasztás folyamatát elfogadható pontossággal le tudja írni az általunk készítette modell, így lehetôségünk van annak kiterjesztésére a vágási folyamatra. A kiterjesztés során az itt meghatározott eredményeinket felhasználva szeretnénk a sugár haladását vizsgálni az anyagban (pl.: egyenes vagy ívelt vonal mentén). Ezáltal egy komplexebb modell segítségével a valós vágási folyamat modellezése is kivitelezhetô, amely alkalmas lehet a technológiai paraméterek optimálására is.

\section{Köszönetnyilvánítás}

Az Innovációs és Technológiai Minisztérium ÚNKP-20-4 kódszámú Új Nemzeti Kiválóság Programjának a Nemzeti Kutatási, Fejlesztési és Innovációs Alapból finanszírozott szakmai támogatásával készült.

\section{Irodalomjegyzék}

[1] Bíró Sz., Különleges technológiák, egyetemi jegyzet, Bánki Donát Gépész és Biztonságtechnikai Mérnöki Kar, Budapest, 2020.

[2] Maros Zs., Az abrazív vízsugaras vágás minôségének és hatékonyságának vizsgálata, doktori értekezés, Miskolci Egyetem Gépészmérnöki és Informatikai Kar, Miskolc, 2011.

[3] M. Kelager, Lagrangian Fluid Dynamics Using Smoothed Particle Hydrodynamics, Department of Computer Science University of Copenhagen, Koppenhága, 2006.

[4] J.J. Monaghan, Smoothed Particle Hydrodynamics, Annual Review of Astronomy and Astrophysics 30, 1992, pp. 543-547, CrossRef

[5] Tóth B., Szabó K.G., Szerkezetek lökésszerú hidrodinamikai igénybevételének numerikus modellezése SPH-val, tudományos diákköri dolgozat, Budapesti Múszaki és Gazdaságtudományi Egyetem, Budapest, 2012.

[6] Tóth B., Sekélyvízú tavak szélkeltette áramlásának modellezése hálómentes módszerrel, Hidrológiai Közlöny, 2018, url

[7] M. Vesterlund, K. Holmlund, Simulation and Rendering of a Viscous Fluid using Smoothed Particle Hydrodynamics, diplomamunka, Umea Universitet, Umea, 2004, url

[8] L. Ma, R. Bao, Y. Guo, Waterjet penetration simulation by hybrid code of SPH and FEA, International Journal of Impact Engineering 35(9), 2008, pp. 1035-1042, CrossRef

[9] Zsoldos I., Korszerú szerkezeti anyagok: Aluminium és ötvözetei, egyetemi jegyzet, Széchenyi István Egyetem, Győr, 2013.

[10] Lovas J., Krállics Gy., Mechanikai Anyagvizsgálat, egyetemi jegyzet, Budapesti Múszaki Egyetem, Budapest, 2004. 
[11] J. Huopana, M.Taborelli, Design of Precision Alignment of Compact Linear Colliders Accelerating Structures, diplomamunka, University of Oulu, Oulu, 2009.

[12] Égert J., Jezsó K., Mechanika, egyetemi jegyzet, Miskolci Egyetem, Miskolc, 2006.

[13] A. Verelst, ALLOY DATA SHEET EN-AW 6060[AlMgSi], Nedal Aluminium BV, Utrecht, 2017.

[14] A.A. Lukyanov, An Equation of State for Anisotropic Solids under Shock Loading, The European Physical Journal B 64, 2008, pp. 159-164, CrossRef 